Chapter 6

\title{
Educating Succeeding Generation Entrepreneurs in Family Businesses - The Case of Slovenia
}

\author{
Mojca Duh, Marina Letonja and Jaka Vadnjal \\ Additional information is available at the end of the chapter \\ http://dx.doi.org/10.5772/58950
}

\section{Introduction}

Succession has been recognized as one of the major problems of family businesses and, for this reason, has become one of the most researched topics in the family business research field [2, $48,50]$. Family businesses represent an important share in the structure of all firms. According to research findings, more than $70 \%$ of all firms worldwide [45] are family ones, most of them being micro, small or medium-sized firms (SMEs). According to some research results, such as [20,32], between $40 \%$ and $80 \%$ of Slovenian businesses are family SMEs, with the majority owned by the first generation of the family [17]. Recently, the discussion in Slovenia has focused on the problem of transferring family firms to the next generation. Family SMEs established in the 1990s are approaching the critical phase of transferring firms to the next generation. Owners/managers of these firms, mostly founders, have practically no experience in managing the succession process due to the lack of a succession tradition in Slovenia. As Slovenia is one of the innovation followers with a below average performance, the enhancement of innovativeness and entrepreneurial orientation of successors and their firms is of crucial importance for the future of Slovenia as an innovative society.

In our study, we will explore family SMEs challenged by succession in Slovenia and how entrepreneurialism (i.e., entrepreneurial competences of successors) and knowledge transfer (from founders to successors) contribute to effective succession in family SMEs. According to many authors, including [52,53], knowledge and the processes of creating new and using existent knowledge are of crucial importance for firms' innovation capability. In our research, we propose that entrepreneurial competences are of crucial importance for the development of capable successors who should bring fresh perspectives in a firm, thereby contributing to the strategic renewal of a firm in the next generation. Our definition of factors that contribute to the formation of entrepreneurial competences is based on research findings of [26] and 
cognitions on entrepreneurship, knowledge, knowledge management and innovations of scholars in family businesses research field, such as [7, 9, 46, 50, 61]. Working experience outside a family firm, family context (i.e., familiness), and formal education (i.e., in entrepreneurship) are recognized in our research as an important factors in building entrepreneurial competences.

The realization of effective succession depends to a great extent on how well a succeeding generation is prepared to take over a leadership and entrepreneurial role [7, 47, 58]. For this reason many research studies have dealt with the nurturing, preparation, and development of successor(s) $[24,41,50]$ as an important predictor of successful succession. Several studies, such as [7, 50, 61], have argued the importance of a successors' education level for smooth and successful realization of succession; the selection of successors is increasingly based on their experiences and skills as well as commitment to a family firm [26]. Successors' educational level should meet requirements needed to be an entrepreneur in a knowledge-based economy, where it is no longer enough just to know how to perform a specific activity or function. Being competitive requires being able to create new knowledge, which also depends on a successor's absorptive capacity established by academic and professional education [64]. The process of getting formal/academic education also exposes successors to new ideas and trends [56]. Successors' experiences gained by working outside the family firm have also been found to be of great importance in developing specific abilities, getting different view of the business, and learning how to do business $[7,9,19,41,67]$. Such experiences are of special importance as they offer exposure to new ideas and perspectives [56] and provide knowledge that is relevant for the future development of a firm's innovation capacity [19, 26]. Tightly linked to the question of preparing a competent leader are research studies dealing with the transfer of knowledge during the succession process [57]. In particular, the transfer of tacit knowledge from predecessor to successor and the successor's training to assume the top management functions have been found to be key processes in developing and protecting knowledge (especially tacit knowledge) and guaranteeing the existence and development of a family business [7, 23].

The main goal of our research is to broaden our understanding of the importance and factors of building entrepreneurial competences for effective succession in family SMEs. The role of formal education in building entrepreneurial competences of succeeding generations is introduced for two cases of educational institutions in Slovenia: the Faculty of Economics and Business, University of Maribor and GEA College, Faculty of Entrepreneurship. Twenty Slovenian family SMEs were used for the case study, which was conducted in order to explore how entrepreneurialism and the transfer of tacit knowledge between a founder and a successor contribute to effective succession in family SMEs. We limit our research on the intra-family business transfer of leadership (i.e., management succession) from the first (i.e., founder) to the second family generation.

The topic researched induced us to adopt a qualitative research approach, where we found the case studies' research method to be the most suitable. Many authors, including [9, 12, 40], have argued that qualitative methods are needed in the field of family business research as this type of business is characterized by complex relationships and interactions that actively 
construct reality. We apply a multiple-case study approach, where replication logic is possible [69]. The twenty cases were carefully selected from a database that the authors of this study have been developing for many years.

We begin our paper with the conceptual framework and an overview of existing research and literature; we continue with the presentation of methodology and empirical findings. We end our paper with conclusions and propositions for future research directions. Implications for practice are presented as well.

\section{Effectiveness of family business succession}

One of the major problems family businesses face in their lifecycle is the transfer of ownership rights and leadership to the next family generation. Some authors, such as [67], even define a family business in terms of a succession. Estimations indicate that only around $30 \%$ of family businesses survive to the second generation because of unsolved or badly solved succession $[48,50]$ and even less succeed to the third generation [41]. A widely accepted differentiation of succession [27, 36, 59] is between succession in management (or so-called leadership succession) and succession in ownership, although in most family SMEs both processes occur simultaneously and go hand-in-hand.

Although succession within a particular family is only one of many possibilities, a majority of family enterprises' leaders desire to retain family control past their tenure [3, 14]. A family member as a successor is especially preferable when so-called idiosyncratic, family businessspecific experiential knowledge is considered highly relevant for gaining a competitive advantage and ensuring the successful functioning of the enterprise [3,55].

Research findings indicate that family business succession should be seen as a process of transferring ownership and management control to a successor [36], characterized by increasing involvement of the successor in the family business [7]. Taking the perspective of a succession as a process, various authors have proposed different models and concepts [36, 41, 43]. As many family businesses fail during or after the realization of transfer to the family's next generation, considerable research attention has been devoted to defining successful succession and identifying predictors of a successful succession process [24, 41, 50]. For example, [59] and [41] defined two dimensions of a successful succession: (1) stakeholders' satisfaction with the succession process and (2) the firm's positive performance and ultimate viability after the realization of the succession. Similarly, authors such as [36, 50] suggest that, when evaluating a family business succession, we should distinguish between the "quality" of the experience and the "effectiveness" of the succession; quality reflects how involved family members experience the succession process whereas effectiveness reflects how others judge the outcome of the succession process.

Several research studies have demonstrated that success of a transition considerably depends on how well the next family generation is prepared to take over a business. According to research findings, members of the next family generation have to develop some critical 
characteristics $[7,47,58]$, such as business and industry knowledge, decision-making abilities, networks and social capital, passion, innovative spirit, and legitimacy and credibility from both family and non-family stakeholders. For this reason, many research studies have dealt with the nurturing, preparation, and development of successor(s) $[24,41,50]$ as an important predictor of successful transition. In their research, [50] found that business transitions occur more smoothly when the heirs are better prepared, and post-transition performance is positively affected by the heirs' education level. The preparation of a competent leader is also seen as an important part of succession planning, which is expected to improve the probability of the success of the transition process [27, 50,51,59] and refers to the deliberate and formal process that facilitates the transfer of ownership and management control. The process of preparing a competent leader should also include knowledge transfer between family generations [57] as the transfer of tacit knowledge from a founder to a successor has been identified as one of the key processes in developing and protecting knowledge and guaranteeing the continuity of a family business [7]. Specific family knowledge has to be transferred to the next family generation, since customers believe that products are of high quality [23]. [57] points to the strategic importance of transferring tacit knowledge to the next generation in order to maintain and develop a family business after the transfer to the next generation. For this reason, different research studies address the role of career development, outside work experiences, apprenticeship, on-the-job training, formal education, and the role of training programs in the process of preparing and developing a competent leader (for references, see [41]).The role of mentoring and the selection of mentoring techniques in family firms were explored by [4]. [47] addressed the issue of training of the next-generation family members after they joined the management team; their findings indicated that involving next-generation family members in the strategic planning process brings benefits to their development. The implications of nepotism for knowledge management were explored by [37], who suggested that generalized social exchange relationships among family members are valuable for firms because they facilitate tacit knowledge management. [9] developed a model that outlines factors responsible for knowledge accumulation in family firms; the model, which is based on findings from four case studies, provides a platform for empirical research as well as suggestions for managers of family firms dealing with issues of knowledge accumulation in order to be successful across generations.

\section{Family businesses and succession issues in Slovenia}

Slovenia's transition from the former socialist economy to the market economy was closely connected with the development of private SMEs, also family SMEs. The social and economic changes created opportunities for establishing private enterprises and enabled family business development. Namely, during the socialist period (starting after World War II and lasting until the early 1990s), the tradition of family businesses persisted mostly within the craft sector. During that period, operating a family firm within the craft sector was not really attractive due to various obstacles (e.g., limitations in employees' number, value of productive resources) $[16,29]$. However, the number of private SMEs increased dramatically since the beginning of 
the transition in the 1990s. According to some of the latest results for the year 2010, there were 126,965 enterprises in Slovenia, of which $99.8 \%$ were micro enterprises ( 0 to 9 employees), small enterprises (10 to 49 employees), and medium-sized (50 to 249 employees) enterprises. Large enterprises (more than 250 employees) represent only $0.2 \%$ of all enterprises in Slovenia and provide $30 \%$ of the nation's jobs. The size structure of enterprises and the employment share in Slovenia are comparable to those in EU-27. However, big differences exist in value added per employee: In EU-27, it is 47,080 €; in Slovenia, it is $29,840 €$, indicating that Slovenian enterprises lag considerably behind EU-27 average value added per employee [49].

Different data and estimations exist regarding the share of family enterprises in Slovenia, mainly due to the use of different definitions and sampling methods. The importance of family businesses for the Slovenian economy is often measured by their share among all enterprises or SMEs (Figure 1). [65] estimated the share of family businesses in employment and value added based on the estimated share of family businesses among SMEs in Slovenia. According to the author's conservative (i.e., bottom-line) estimation, family businesses employ at least $26 \%$ of the active adult population and contribute $22 \%$ to the total value added in the Slovenian economy.

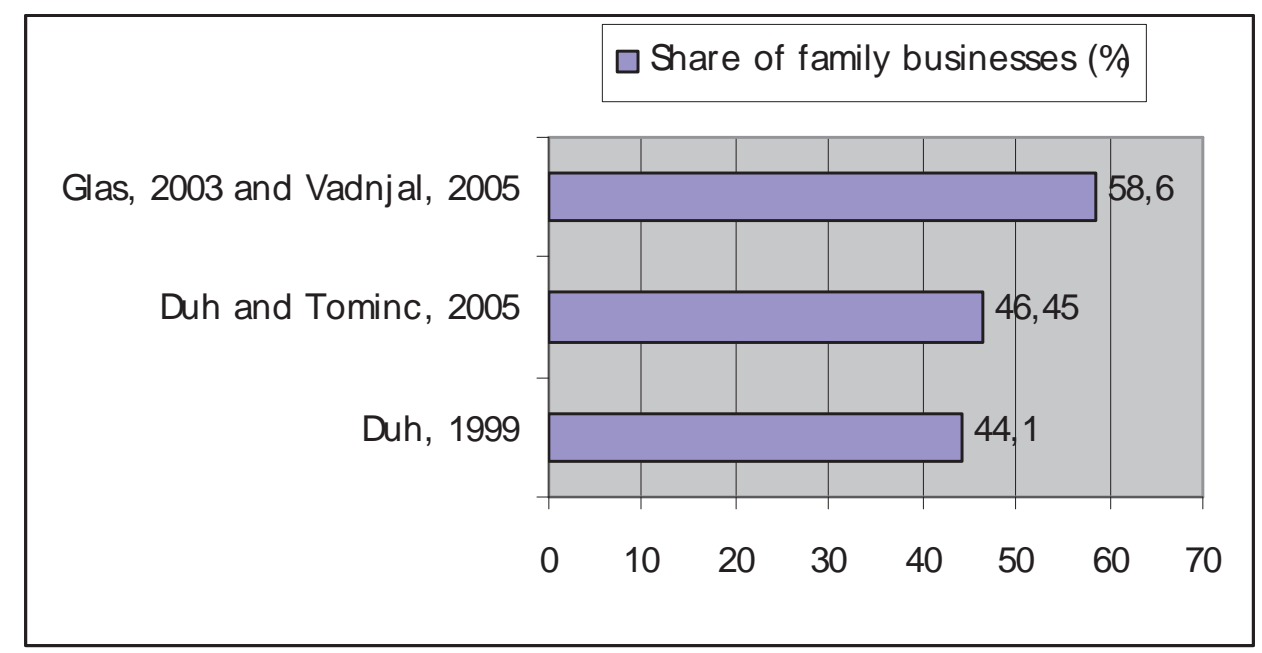

Source: [18]

Figure 1. Estimations of the share of family enterprises in Slovenia

Other estimates indicate an even higher share of family enterprises, falling in the range of $60 \%$ to $80 \%$ [32], contributing 30\% of the GDP [66]. [21] estimated the number of family enterprises in different class sizes in Slovenia, finding that micro family enterprises prevail in Slovenia.

Recently, the discussion in Slovenia has turned to the problem of transferring family firms to the next generation. Family firms established in the 1990s are approaching a critical phase of 
transferring ownership and management to the next family generation. Research findings indicate that the majority of Slovenian owners/managers believe that a business should stay in a family $[20,28,30]$. Regarding succession in management, research results [20] indicate that the majority of respondents decided to realize the succession within the family. Other options, such as transfer to the employees/management or closure of a firm, occur less frequently. Similarly, the majority of respondents reported on realizing ownership succession within the family and less frequently on other options.

Slovenian owners/managers believe that children should be introduced into a business at an early age and be educated about the business needs. Furthermore, they believe only one successor and not a team should take over the leadership; a successor should be found among family members as a business is considered stronger with family members involved. Slovenian owners/managers are quite sure about the capabilities of their children to take over and manage a family business. They also believe that children should become co-owners when they join a business and when their parents are active in the business $[28,30]$. The concept of "primogeniture," where the oldest child takes over a business, is firmly present in Slovenian family businesses, although the gender aspect is not that important. The most common way of transferring a family business is through the gift process; owner-managers are not inclined to the idea of selling a business [44]. Another research finding indicates that the succeeding generation wants to retain more freedom when deciding about entering a family business. Successors lack a proper training and mentoring and, therefore, feel uncertain about their capability to manage a firm [31]. As the majority of Slovenian family businesses are still under the ownership and management of the founding generation, many lack succession experiences $[20,22,29]$.

The research findings of [20] show that less than $60 \%$ of Slovenian family business owners/ managers are actually planning the succession. One fifth of Slovenian owners/managers even believe that succession planning is not necessary. Similarly, [44] found that a situation is better among owners/managers who are older than 50 years, although $20 \%$ of them still believe that succession planning is not necessary.

An analysis of institutional actors and policy actions in Slovenia demonstrates that different actors as well policy measures and actions exist that support and promote SMEs and other business organizations; however, family businesses are not recognized as a special group within SMEs. Some efforts have been undertaken in research; educational support also exists, provided mainly as special courses, and special training and consulting activities are also offered (e.g., by the Chamber of Craft of Slovenia) [18].

\section{Preparing the next generation to take over leadership control}

\subsection{Entrepreneurial competences}

According to the opinion of several authors, succession should not be treated as a threat, but rather be seen as an opportunity to more effectively address fast-changing marketing condi- 
tions when an incumbent is replaced with a more capable leader [24] and as a way of enhancing the level of entrepreneurship [26]. For this reason, not only the transfer of knowledge between family generations is of importance for the future of a family business (as explained in the next subchapter), but the next generation should also have access "to new bodies of knowledge that are relevant for the future development of firms' innovation capacity" [26, p. 14] in order to avoid the conservatism and closeness often present in older family firms [68].

Based on these cognitions, we argue that entrepreneurial competences of successors are of crucial importance for the smooth and effective realization of succession and for the innovativeness and viability of a family business in the next family generation. According to [26], entrepreneurial competences should be understood as attitudes toward problem solving, entrepreneurship, social relationships, risk, negotiation, and teamwork as well as creativity, working commitment, communication and motivating skills, technical, marketing, and administrative knowledge and competences. Similarly, [42] identified factors leading to innovation at the individual level. The main factors contributing to the formation of successors' entrepreneurial competences are [26]: formal education (i.e., in entrepreneurship), work experiences outside the family firm, and a family context ("familiness"). These factors are explained in the following subsections.

\subsubsection{Formal education}

Many research findings provide support for the significant relevance of the educational level for a successor's performance and effectiveness of a succession process [7, 50, 61], and the successor's educational level is becoming an important selection criterion [26]. A successor should be trained as an entrepreneur at the academic level [26] and be exposed to new ideas and trends in management and business in the process of obtaining a formal education [19]. In the fast-changing competitive environment, it is no longer enough to know how to perform a specific activity; an ability to create new knowledge is also of crucial importance. Formal education enhances a successor's absorptive capacity, thereby also influencing his/her capability to acquire and create new knowledge [19] and enabling successors to better articulate and structure the knowledge-transfer process [26]. The formal education of successors should emphasize skills like critical thinking, creativity, communication, user orientation, and teamwork as well as using domain-specific and linguistic knowledge. As entrepreneurship studies cover all these, we present two cases of educational institutions in Slovenia in the next chapter.

\subsubsection{Working experiences outside a family business}

A successor's preparation should not be limited to knowledge transfer between the founder and the successor (although it is also very important). Successors should also be exposed to a wide range of experiences, meaning that "[a] junior entrepreneur should not only be socialized in the existing context of interactions, he/she should be also familiarized with other contexts" [26, p. 14]. Working outside a family firm provides successors with "a more detached perspective over how to run and how to introduce changes and innovation in the business" [9, p. 447]. Experiences gained in this way enable successors to access "new bodies of knowledge 
that are relevant for the future development of firms' innovation capacity" [26, p. 14]; they also help successors replenish, increase, and upgrade the knowledge basis [7]. The right combination of internal and external training experiences are important for acquiring technical and managerial knowledge and leadership abilities [7] that play a crucial role in creativity and innovation [42]. This is of special importance as research findings indicate that family firms tend to become more conservative and less innovative over time [13, 68].

\subsubsection{Familiness}

[33] suggested that family firms are often "rich in intangible resources". The resource-based view allows consideration of an "idiosyncratic, immobile, inimitable, sometimes intangible bundle of resources" that to varying degrees commonly resides in a family firm. Within this view the term "familiness" has been developed and widely accepted to describe the unique bundle of resources held by and particular to family firms as a result of their unique systems, interaction among the family, individual members, and the business itself, leading to positive synergies $[7,11,33]$.

According to [60], familiness is a resource that is unique to family firms; it is a specific bundle of attributes derived from a family's culture [8] and a unique form of family culture [35]. It is an imperfectly substitutable/exchangeable resource in the manner described by [1]. According to [34], it is the set of resources controlled by a firm resulting from a continuous overlap of a family system with the business system in a firm. According to [7], a predecessor and a family have great influence on a successor in terms of cultural values and entrepreneurial attitudes and behaviours.

The authors agree that familiness is closely related to the concept of family business culture. Successful family firms are those which share family culture thereby remaining competitive also after transition between generations. This "effective family culture" is characterized by joined view of the world and a wish to succeed [8]. Family members (e.g., successors) who are socialized at home bring this shared culture in the family business. According to [8], this "effective family culture", provides foundation for familiness in the family firm. Since family culture's mechanisms are tacit, they are difficult to transfer to outsiders or to persist over family generations. Familiness of the business depends on whether a family succeed to transfer the tacit family culture to the family business. Since a business with more familiness will gain a competitive advantage, such owning family should be more likely to retain the family business within the founding family [8].

\subsection{Tacit knowledge transfer}

In the family business literature, the transfer of tacit knowledge from predecessor to successor has been found to be one of the key processes in developing and protecting knowledge and guaranteeing the continuity of the family business [7]. It is of crucial importance to understand how and in which way predecessors transfer their tacit knowledge to successors as this enables the successor to get hands-on knowledge about a family firm and an industry. As pointed by [26, p. 13], "the process of knowledge sharing is fundamental because it stimulates people 
creativity through interactions". This is why we explored different ways and approaches of tacit knowledge transfer from founders to successors.

Several authors [7, 27] have stressed the importance of a successor's early exposure to a family business (e.g., through summer and lower category jobs) in order to provide the successor with valuable experiences and the founder's tacit knowledge; this is of particular importance during the transfer from the founding to the second generation. Conversation about a firm at home is also an approach that enables a successor to absorb tacit knowledge about the business as "conveying the psychological legacy of the firm is an important part of child rearing from the beginning" [27, p. 71]. Mentoring is also an important way of enhancing the successor's knowledge [7, 9] as close interactions between founders and their successors are a superior form of experience supporting the development of tacit knowledge by successors. However, no common agreement exists on whether parents are the most suitable mentors [27], and diverse opinions exist regarding the role of formal and informal mentoring [4]. Apprenticeship is found to be an effective way of transferring tacit knowledge between generations, especially in traditional industries that do not operate in environments of rapid change [9]. The learning-by-doing process can be an excellent opportunity for younger generations to learn directly from the previous generation, "especially, all the 'tricks of trade' related to the business" [9, p. 441].

Working together (e.g., in a team) is also an important way of transferring knowledge across family generations and is particularly important as it facilitates creative interactions between generations, thereby contributing to the entrepreneurial and innovative orientation of a family firm [10, 42]. Different approaches to such joint work are identified in the literature, including the successor's active participation in decision making [38], involvement of the next-generation family members in the strategic planning process [47], and teamwork [26, 42].

\section{Case of Slovenia}

\subsection{Case study method}

We decided to apply a qualitative research approach that is significant for family business research [54]. The nature of our research and research questions addressed are the reason for the use of the case study method as it has been shown to be well-suited methodology, especially in those studies "in which there are manifold variables of interest that are embedded in the context of investigation" [12, p. 16]. It is of particular importance for and the most adopted qualitative method in organizational studies [25] as well as in family business research studies. For example, [12] viewed "case studies as a powerful methodology that can be used in a rigorous, creative and wide-ranging variety of ways to advance family business research" (pp. 15-16). We applied an exploratory case study as the main aim is "to understand how phenomenon takes place" [12, p. 16], and the research question addresses how entrepreneurialism and the transfer of tacit knowledge between a founder and a successor contribute to effective succession in family SMEs. 
We applied a multiple-case study approach [69] due to its acceptance in the family business research [10,12] as this allows us to analyse within each setting and across settings [12]. There are different opinions regarding the number of cases; for example, [25] suggests that between four and ten cases are best for increasing rigor. We selected twenty cases from the family business database, where data on Slovenian family businesses have been collected by the authors of this contribution for many years. In addition, we explore two cases of institutional support in entrepreneurship education.

\subsection{Sampling, data collection, and analysis}

Twenty cases of Slovenian family firms were carefully selected from the database. We included micro (0 to 9 employees), small (10 to 49 employees), and medium-sized family firms (50 to 249 employees) as, in these size classes, family businesses of the first generation prevail in Slovenia and the family exerts strong and direct control over the business. In addition to the firm's size, an important limitation in selecting cases was the family generation in charge. We limited our research on succession from the first to the second generation; thus, only those cases in which the founder was still employed in the firm, owned the firm, or was active in the firm (although he/she is retired) as well as when a member of the next family generation was involved in the family business were selected. As there is no common definition of a family business [45], we defined it as any firm in which a founder (i.e., an owner/manager) considers it to be a family business.

Data were gathered through direct interviews conducted between February and March 2014; additional data were collected through direct observations and documentation, thereby enhancing data credibility [12]. We conducted at least two interviews per case, with the founder and the successor. We found them to be well-informed interviewees who "view the focal phenomenon from different perspectives" [12, p. 19]. [54] suggested conducting 30 interviews to cover both the breadth and depth of the research topic. Therefore, we believe that the conducted interviews provided us with a sufficient quantity of high-quality data needed to ensure a strong qualitative study. All interviews took place at workplaces in family businesses on workdays.

Data gathered were analysed systematically; data collection and analysis were done several times concurrently, as is often the case in qualitative methods [12]. After organizing and arranging data, a cross-case comparison was conducted. We based the presentations of the results on the method of [25], which is "grounded in a positivist tradition and based on comparative case analysis" [54, p. 99]; following this method, the results are presented in tables (with the exception of two institutional cases) that display "concise, consistent summary points of each case which facilitates comparisons" [54, p. 99]. The empirical results were compared and contrasted with the established literature. The main findings are presented in the next subchapter. 


\subsection{Findings}

\subsubsection{Formal/academic entrepreneurship education of successors - Cases of the two institutions}

\section{Case 1: Faculty of Economics and Business}

The Faculty of Economics and Business (FEB) is one of 17 faculties of the University of Maribor, located in Maribor, which is the second largest city in Slovenia. FEB was established in 1959 as the School of Economics and Commerce; today FEB offers several accredited and, in its environment, well-accepted study programs at the undergraduate, master's, and doctoral degree levels. These programs are prepared in accordance with the requirements of the Bologna Declaration $(3+2+3$ model). FEB has been implemented the first-cycle university education program "Economic and Business Sciences" and the professional higher education program "Business Administration" together with the second-cycle master's program "Economic and Business Sciences" since 2006, while the third-cycle doctoral program "Economic and Business Sciences" has been running since 2008. Most study programs are implemented as both full-time and part-time studies [39]. Whereas the first cycle lasts three years (180 ECTS), the master program (second cycle) lasts two years (120 ECTS). The third cycle (i.e., the research-oriented doctoral program) lasts three years (180 ECTS) and is open to graduates from the second cycle.

The university program "Economic and Business Sciences" offers eight fields of study: (1) accounting, auditing and taxation, (2) business management and organization, (3) e-business, (4) economics, (5) entrepreneurship, (6) finance and banking, (7) international business economics, and (8) marketing. The university program consists of totally 30 courses. Out of these 30 courses, 16 courses are common to all study fields and 6 courses are field of study courses. 8 courses are electives and are chosen by the student. In the "Business Administration" professional higher education program, students can specialize in eight fields of study: (1) accounting and business taxation, (2) business finance and banking, (3) entrepreneurship, (4) international management, (5) management, (6) marketing, (7) public sector economics and management, and (8) tourism. The program consists of 16 common courses, 6 study field courses, and 6 elective courses in addition to practical training in the second and third years of study. In both undergraduate study programs, students prepare a final diploma project. The "Economic and Business Sciences" master's program offers nine fields of study: (1) accounting, auditing and taxation, (2) economics, (3) entrepreneurship and innovation, (4) finance and banking, (5) information systems and e-business management, (6) international business economics, (7) management, organization and human resources, (8) marketing management, and (9) strategic and project management. The program comprises 10 courses, of which one is common to all fields of study and two are electives; the others are all field of study courses. The master's thesis is students' final obligation.

As our main research concern is entrepreneurship education for the family businesses' successors, a more detailed exploration of the entrepreneurship field in both undergraduate study programs as well as the entrepreneurship and innovation master's program will be conducted. The doctoral program is not explored in detail due to its research focus. In addition, we will explore the two undergraduate courses dealing with family business topics. 
The main goal of the university's entrepreneurship program is "to acquire knowledge in entrepreneurship that enables developmental and operative management of small and medium-sized enterprises, implementation of intrapreneurship, leading of independent business plans and programs in large enterprises, establishing of own enterprises or takingover existing family businesses" [5]. In order to realize this main goal, in addition to common and elective courses, the study program offers the specialized courses in marketing research, entrepreneurship, innovation management, dynamic entrepreneurship, managerial economics, and corporate entrepreneurship. These courses are offered in the second and third year of studies, while the first year covers common courses (i.e., basics of organization and management, mathematics for economists, introduction to economics and microeconomics, introduction to business information systems, business law, business economics, fundamentals of marketing, accounting, fundamentals of finance, macroeconomics); some common courses are in the second and third year as well (i.e., statistics, corporate finance, business policy, and strategic management). Foreign language as a year-long course is part of the program in all three years.

The entrepreneurship program in the professional higher education program includes common courses mainly in the first year (i.e., basics of organization and general management, foundations of business economics, business law, sociology, business mathematics, fundamentals of marketing, accounting, business information systems, finance for business, foreign language as a year-long course). In the second and third years, students attend field of study courses (i.e., entrepreneurship, business environment, European law, corporate entrepreneurship, business growth, operational management), common courses (i.e., economic policy, business statistics, basic cost and management accounting, e-business, business policy, and strategic management) and elective courses in addition to two practical trainings in selected firms.

At the master's degree level, the entrepreneurship and innovation program provides students with knowledge that enables them to manage their own enterprise and invention-innovation processes as well as make decisions in developmental oriented organizations [6]. The only common core course focuses on research methods. Students also obtain specialized knowledge in theories of the firm, invention and innovation management, technological and environmental innovations, development of a dynamic enterprise, entrepreneurship theories, international entrepreneurship, and law of intellectual property.

Family business-related topics are offered within two courses. The family business management course is an elective for second-year students of the university program. It covers family business characteristics, the role and importance of family enterprises for the economy and society, family in a family business (the role of family members, family relationships and conflicts, family values and interests), succession (family and individual lifecycle, lifecycle of a family business, succession as a process, succession planning), and management particularities. In more detail, the particularities of management are taught in the business policy and strategic management course, which is a common obligatory course in the university as well as in the professional higher educational program, although the course is more practically oriented for the latter program. Management particularities are discussed in the class from 
three different perspectives: management as a process (hierarchy of the process and management functions), management as institutions (e.g., structure of leading bodies, such as the board of directors, executives, their responsibilities), and management as a system of instruments (e.g., different planning tools and methods, leadership styles and techniques). In particular, the role and influence of a family in management are presented.

The FEB offers a comprehensive and quality entrepreneurship education in both undergraduate and master's level fields of study. Potential family business successors can upgrade their knowledge with family business specifics. In particular, the two courses that address the particularities of family business functioning and management are useful providers of knowledge for all those who are going to work in or with family businesses.

\section{Case 2: GEA College-Faculty of Entrepreneurship}

GEA College-Faculty of Entrepreneurship (GEA-FE) is the leading private business school in Slovenia, with more than 20 years of experience in the provision of courses focused on entrepreneurship. Eighteen generations of students have been enrolled, culminating in more than 1400 undergraduate- and 150 master's-level graduates. Entrepreneurship is and will remain the main study discipline of GEA-EF for those who want to learn not only about entrepreneurship, but also for entrepreneurship. The institution provides high-quality, practically oriented undergraduate (3 years, full-time study program) and postgraduate courses (master's level, 2 years, part-time study program), but it does not offer doctoral studies. The final qualification of the first cycle of the higher professional study program is the bachelor's degree in economics, and the second cycle of the higher professional study program's final qualification is the master's degree in business administration. The programs are accredited by the Ministry of Education of the Republic of Slovenia. For this reason they are recognized worldwide. The study programs are consistent with the Bologna Declaration $(3+2)$ and the European Credit Transfer System (ETCS) thereby enabling full mobility of GEA-FE students. The first cycle is accredited with 180 ECTS, and the second with 120 ECTS. The institution is also a full member of various leading international associations of business and managements schools.

In the GEA-FE vision expresses the intent to become one of the leading schools in training and education of entrepreneurs in Central and Eastern Europe. Its evolvement into the centre for creating and implementing excellent projects in entrepreneurial education that are based on innovative entrepreneurship programs is stressed as well. Especially, innovations and entrepreneurial pragmatism are defined as the key values. The mission of the GEA-FE is to support entrepreneurs in acquiring new knowledge and skills in order to become competitive and successful in the market economy. Therefore, it searches, creates and transfers new knowledge, educates and trains young people.

The main objectives of the GEA-FE programs are to enhance business thinking among individuals and encourage business activities among young people. The main intention of the study programs is to encourage young people to think about and develop new business opportunities and eventually establish their own enterprises. It is estimated that more than $40 \%$ of the students are coming from families running family firms. Students develop both 
general and specific skills; general skills especially in the field of entrepreneurship, economics, and management, and specific skills for entrepreneurship (i.e., international cooperation, management, innovation, creativity, business growth, project management, marketing, and finance).

Case studies, project work, team problem solving, classroom visits and business evenings by successful entrepreneurs, and student exchanges with foreign universities are undertaken during the study process in order to combine theoretical knowledge with practical experiences. These methods proved to be excellent processes of educating students to become successful entrepreneurs. The programs are tailor-made education and training for successful entrepreneurs. GEA-FE applies the modern teaching methods that are recognized by many acknowledged universities and higher education institutions in Europe and the USA. The study process is done in small groups of students in order to promote both individuality and interactivity. Internship as the practical application of the knowledge gained is an obligatory part of students' training within the framework of study at the GEA-FE. The cooperation with small, middle, and larger companies is recognized as an important part of the study process. Students have the opportunity to actively participate in projects and research that are done for and in selected companies. This enables students to share knowledge and experiences on growth, capitalization, strategy, vision, and market research with owners and/or managers.

Family business-related topics are offered within the family entrepreneurship course, which is an elective course offered to the students of the second or third years of the first level of the higher professional study program. It covers the purpose and specifics of family firms (significance for national economies, in the EU and worldwide, main roles in family firms, the role of founders in family firms, strengths and weaknesses of family firms), conflicts in family firms (in the same generation, between generations, ways to solve conflicts, strategic and development directions of family firms and family firms' vision), growth and development of a family firm (satisfaction/dissatisfaction with economic and non-economic parameters of business operations, succession, long-term family firm orientation), legal aspects of family firms (the role of the family in human development, family as a working group, definition of healthy family relationships, basis of family therapy), and support environment for family firms (consulting and training for family firms). The course is accredited with 6 ECTS [63].

The second level of the higher professional program consists of two courses: strategic aspects in entrepreneurship and management in entrepreneurship. Each course offers 3 fundamental, 1 obligatory, and 3 elective courses (to be chosen out of 5). The fundamental courses are entrepreneurship and organizational growth management, managerial economics, and quantitative research methods. Business forecasting and growth strategies or development of HR capabilities and influence of the EU are among obligatory courses. Elective courses are standards of business ethics and culture in the EU, franchising and trademark enforcement, global marketing, private law, venture capital or operations management, strategic management, project management, business view of communication in entrepreneurship, and entrepreneurial challenges of the global economy. In the first year of study, students have to select two fundamental courses and one obligatory course as well two or three elective courses depending on their study course. Students can choose the third elective course from the courses 
offered by the GEA College or any other higher educational institution in Slovenia or abroad. In the second year, the course quantitative research method is obligatory for students. The fourth semester ends with a master's thesis [64].

\subsubsection{Twenty case studies}

We interviewed family business owners/managers and their successors in 20 family firms coming from different industries from production of carpentry, textile clothing, faucets, concrete products, jewellery, sport equipment, toys, pellet stoves, car batteries from the wholesale and retail trade of cars, textiles, carpentry, organic food, sanitary equipment, transport and logistics, and other car services (Table 1). The sample of companies was regionally dispersed as there were $6(30 \%)$ companies from the Podravje region, 5 (25\%) from the Osrednjeslovenska region, $2(10 \%)$ from the Gorenjska region, $2(10 \%)$ from the Savinjska region, 2 (10\%) from the Notranjska (Carst) region, 1 (5\%) from the Prekmurje region, 1 (5\%) from the Primorska region, and 1 (5\%) from South-East Slovenia (Dolenjska region). There were 7 (35\%) medium-sized companies, $8(40 \%)$ small companies, and $5(25 \%)$ micro companies included in the sample. All founders (100\%) were active in their companies. Ownership and management had been totally transferred to the successors in $3(15 \%)$ companies, partly transferred to the successors in 2 companies (10\%), and partly (ownership) and entirely (management) transferred in $3(15 \%)$ of the companies; in 7 (35\%) of the companies, ownership and management had not been transferred to the successors, 4 (20\%) founders transferred management but not ownership to their successors, and $1(5 \%)$ partly transferred ownership but not management to the successor.

\begin{tabular}{|c|c|c|c|}
\hline Case no. & Industry & $\begin{array}{l}\text { Established (year)/ } \\
\text { current generation }\end{array}$ & Short description of company specifics \\
\hline 1 & $\begin{array}{l}\text { Production of } \\
\text { carpentry from wood, } \\
\text { plastic, aluminium }\end{array}$ & 1990/second & $\begin{array}{l}\text { A leading producer of carpentry from plastic, aluminium, and } \\
\text { recently from wood, awarded with golden medals for their } \\
\text { wooden and wooden-alu pasiv windows; the founders retired, } \\
\text { present in the supervisory board and procuration, } \\
\text { management transferred to the son-in-law and daughters, } \\
\text { ownership transferred partly to daughters. Medium-sized } \\
\text { company. Podravje region. }\end{array}$ \\
\hline 2 & $\begin{array}{l}\text { Road transport and } \\
\text { logistics }\end{array}$ & 1992/first & $\begin{array}{l}\text { A road transport and services provider. The founders have } \\
\text { transferred management, but not ownership to the successors. } \\
\text { One is retired, but is active. Medium-sized company. } \\
\text { Gorenjska region. }\end{array}$ \\
\hline 3 & $\begin{array}{l}\text { Production of sport } \\
\text { equipment }\end{array}$ & 1987/second & $\begin{array}{l}\text { A micro company developing sports equipment, holding } \\
\text { patents, producing short skis and accessories for skis; founder } \\
\text { just retired, has been actively present, but ownership and } \\
\text { management are being transferred to the successor. Gorenjska } \\
\text { region. }\end{array}$ \\
\hline
\end{tabular}




\begin{tabular}{|c|c|c|c|}
\hline Case no. & Industry & $\begin{array}{l}\text { Established (year)/ } \\
\text { current generation }\end{array}$ & Short description of company specifics \\
\hline 4 & $\begin{array}{l}\text { Wholesale trade and } \\
\text { production of toys }\end{array}$ & 1991/first & $\begin{array}{l}\text { A small company importing toys and developing and } \\
\text { producing games for children. Management and ownership in } \\
\text { hands of the founders. Successors are active in the company. } \\
\text { Notranjska - Carst region. }\end{array}$ \\
\hline 5 & $\begin{array}{l}\text { Maintenance and } \\
\text { repair of motor } \\
\text { vehicles }\end{array}$ & 1995/first & $\begin{array}{l}\text { One of the leading companies in the car glass repair industry. } \\
\text { Due to the death of one of the founders, part of the ownership } \\
\text { is in a transition phase, successors are active in the company. } \\
\text { Small company. Osrednjeslovenska region. }\end{array}$ \\
\hline 6 & $\begin{array}{l}\text { Production of } \\
\text { jewellery }\end{array}$ & 1999/second & $\begin{array}{l}\text { The leading producer of jewellery, trading precious metals and } \\
\text { stones. Ownership and management are being transferred } \\
\text { from founder to his successors. Founder active in the company, } \\
\text { but retired. Medium-sized company. Savinjska region. }\end{array}$ \\
\hline 7 & $\begin{array}{l}\text { Production of pellet } \\
\text { stoves }\end{array}$ & 1994/first & $\begin{array}{l}\text { A developer and producer of pellet stoves, holding patents. } \\
\text { Management and ownership in hands of the founder. } \\
\text { Successor is active in the company. Small company. Podravje } \\
\text { region. }\end{array}$ \\
\hline 8 & $\begin{array}{l}\text { Production of car } \\
\text { batteries }\end{array}$ & 1974/first & $\begin{array}{l}\text { A developer and producer of car batteries and garden } \\
\text { equipment. Management has already been transferred, but not } \\
\text { ownership; founder retired, active in the company. Small } \\
\text { company. Dolenjska region (South-East Slovenia). }\end{array}$ \\
\hline 9 & Wholesale trade & 1992/first & $\begin{array}{l}\text { The company is specialized for wholesale trade with } \\
\text { Macedonian products. Management has already been } \\
\text { transferred to the successor, but not ownership. Founder } \\
\text { retired, but remains active in the company. Micro company. } \\
\text { Osrednjeslovenska region. }\end{array}$ \\
\hline 10 & $\begin{array}{l}\text { Wholesale trade and } \\
\text { services-sanitary } \\
\text { equipment }\end{array}$ & 1992/first & $\begin{array}{l}\text { The company is specialized in the development of sanitary } \\
\text { equipment. Management and ownership have been partly } \\
\text { transferred to the successors. Founder is employed. Successors } \\
\text { are active in the company. Small company. Primorska region. }\end{array}$ \\
\hline 11 & $\begin{array}{l}\text { Road transport, } \\
\text { logistics, services, } \\
\text { trade }\end{array}$ & 1989/second & $\begin{array}{l}\text { One of the biggest road transport companies. Ownership and } \\
\text { management have been transferred from the founder to the } \\
\text { wife and successive children. Founder retired, but active in the } \\
\text { company. Medium-sized company. Osrednjeslovenska region. }\end{array}$ \\
\hline 12 & $\begin{array}{l}\text { Retail trade-cars, } \\
\text { service }\end{array}$ & 1990/second & $\begin{array}{l}\text { One of the strongest car traders. Management has been } \\
\text { transferred to the external manager and the successive } \\
\text { children. Ownership has been partly transferred. Founders } \\
\text { have retired and are active in supervisory board. Medium- } \\
\text { sized company. Podravje region. }\end{array}$ \\
\hline
\end{tabular}




\begin{tabular}{|c|c|c|c|}
\hline Case no. & Industry & $\begin{array}{l}\text { Established (year)/ } \\
\text { current generation }\end{array}$ & Short description of company specifics \\
\hline 13 & $\begin{array}{l}\text { Production of } \\
\text { products from } \\
\text { concrete for } \\
\text { construction industry }\end{array}$ & 1990/first & $\begin{array}{l}\text { A company with a strong tradition in production of concrete } \\
\text { products. Management and ownership have been partly } \\
\text { transferred to the successors. Founders and successors are } \\
\text { active. Small company. Notranjska region. }\end{array}$ \\
\hline 14 & $\begin{array}{l}\text { Wholesale and retail } \\
\text { trade with car spare } \\
\text { parts and services }\end{array}$ & 1986/first & $\begin{array}{l}\text { The leading car-glass repair company. Ownership and } \\
\text { management are in the hands of founders. Founders active. } \\
\text { Successors employed and involved in management. Small } \\
\text { company. Podravje region. }\end{array}$ \\
\hline 15 & $\begin{array}{l}\text { Wholesale and retail } \\
\text { trade with metal } \\
\text { products, production } \\
\text { of faucets }\end{array}$ & 1996/first & $\begin{array}{l}\text { A developer and producer of faucets. Holding patents. } \\
\text { Founder retired, active in the company. Ownership and } \\
\text { management not transferred. Successors active in the company. } \\
\text { Micro company. Podravje region. }\end{array}$ \\
\hline 16 & $\begin{array}{l}\text { Production of } \\
\text { working clothing }\end{array}$ & 1978/first & $\begin{array}{l}\text { A developer and producer of working clothing. Ownership } \\
\text { and management not transferred, although both founders } \\
\text { retired. Successors active in the company. Medium-sized } \\
\text { company. Savinjska region. }\end{array}$ \\
\hline 17 & $\begin{array}{l}\text { Sauna, cosmetics, } \\
\text { wholesale and retail } \\
\text { trade }\end{array}$ & 1971/second & $\begin{array}{l}\text { A long tradition of the first sauna and later cosmetics studio. } \\
\text { The founder is retired but active in the company. Successors } \\
\text { are managing the company, ownership has been partly } \\
\text { transferred. Small company. Osrednjeslovenska region. }\end{array}$ \\
\hline 18 & $\begin{array}{l}\text { Wholesale and retail } \\
\text { trade textile }\end{array}$ & 1992/first & $\begin{array}{l}\text { Company is present throughout Slovenia through own shops. } \\
\text { Ownership and management have not been transferred. } \\
\text { Successor is active in the company. Medium-sized company. } \\
\text { Prekmurje region. }\end{array}$ \\
\hline 19 & Sport club, restaurant & 2009/first & $\begin{array}{l}\text { Company is active in the field of sports activities (sport club), } \\
\text { accounting, and family runs a restaurant. Ownership and } \\
\text { management have not been transferred. Successor is active in } \\
\text { the company. Micro company. Osrednjeslovenska region. }\end{array}$ \\
\hline 20 & $\begin{array}{l}\text { Retail trade-organic } \\
\text { food }\end{array}$ & 1989/first & $\begin{array}{l}\text { A pioneer on the field of trading organic products in Slovenia. } \\
\text { Ownership not transferred. Management transferred to the } \\
\text { successor. Founder active and in procuration. Micro company. } \\
\text { Podravje region. }\end{array}$ \\
\hline
\end{tabular}

Table 1. Data on family firms interviewed

Table 2 introduces the characteristics of the sample from the aspects of the founders' and the successors' formal education, external working experiences, and "familiness" as well as the importance of each of them in the eyes of founders and successors. 


\begin{tabular}{lllcc}
\hline \multirow{2}{*}{$\begin{array}{c}\text { Entrepreneurial } \\
\text { competences }\end{array}$} & \multicolumn{2}{c}{ Founder (comment frequency) } & \multicolumn{2}{c}{ Successor (comment frequency) } \\
\cline { 2 - 5 } & \multicolumn{1}{c}{ Done } & Found important & Done & $\begin{array}{c}\text { Found } \\
\text { important }\end{array}$ \\
\hline Formal education & $6(30 \%)$ vocational, & 17 & $16(80 \%)$ higher professional & 20 \\
& $5(25 \%)$ high school, & $(85 \%)$ & or university degree, & $(100 \%)$ \\
& $9(45 \%)$ higher professional or & $1(5 \%)$ high school, & 20 \\
\hline university degree & & $3(15 \%)$ students & $(100 \%)$ \\
External working & $18(90 \%)$ & 18 & 8 & $(40 \%)$ \\
\hline "Familiness" & & $(90 \%)$ & & 20 \\
& & 20 & & $(100 \%)$ \\
\hline
\end{tabular}

Table 2. Formal education, external working experiences, and "familiness"

Formal education is not as important for $3(15 \%)$ of the founders. Instead, they emphasized the importance of experience and a broad understanding of the business. The rest of the interviewed founders found formal education to be especially important for the generation of successors. Successors are mostly very well educated, although mostly in the fields of economics and business/entrepreneurship, which are less technical fields.

Regarding external work experiences, the research results show that only $2(10 \%)$ of the founders started their business with no previous experience; all others (90\%) had previous work experience, albeit not always from relevant fields, although they all found the experiences to be very important. Twelve $(60 \%)$ successors had no previous work experience in other firms, whether in the same or different industries. Three (15\%) had experience in other firms, in the same and different industries. Six (30\%) completed internships in other firms, mostly in different industries, and 4 (20\%) completed internships abroad, mostly as Erasmus exchange students or as part of their training as business partners.

According to the founders, familiness is a unique resource and highly important for the sustainability of a family firm. Sixteen $(80 \%)$ successors found familiness to be very important for developing working commitment, 14 (70\%) for developing attitude toward entrepreneurship, $20(100 \%)$ for the development of social relationships, and $10(50 \%)$ for the development of attitude toward risk.

The following quotes were taken from the interviews.

"Formally educated people are more open to the external environment. They have a lot of general knowledge, but at the professional level they all fail the exam. Practice, practice, practice: it is extremely important."

“...academic knowledge broadens young people's horizons and gives a good basis for using knowledge in practice... thus, you can more easily compete with your competition...."

“...I could not afford to study myself, and I gladly support my child's education..." 
"The next generation must study to understand new technologies, they have to acquire maximum theoretical knowledge, but then-experiences count more and more..."

“...academic knowledge helps you recognize more potential solutions..."

"I would love to work in another company and get external experience and insight into other working environments, especially in a large firm, but the economic situation in the country does not enable this experience.... And the family firm needs me..."

Most founders and successors concluded that familiness is a matter of trust.

Table 3 reveals the picture of the knowledge transfer in the studied sample from the aspect of founders and successors and how important they found each form of knowledge transfer for the successful integration of successors in family firms.

\begin{tabular}{ccccc}
\hline \multirow{2}{*}{ Knowledge transfer } & \multicolumn{2}{c}{ Founder (comment frequency) } & \multicolumn{2}{c}{ Successor (comment frequency) } \\
\cline { 2 - 5 } & Done & Found important & Done & Found important \\
\hline Early exposure & $19(95 \%)$ & $20(100 \%)$ & $19(95 \%)$ & $20(100 \%)$ \\
\hline Mentoring & $9(45 \%)$ & $19(95 \%)$ & $17(85 \%)$ & $20(100 \%)$ \\
\hline Apprenticeship & $10(50 \%)$ & $6(30 \%)$ & $10(50 \%)$ & $10(50 \%)$ \\
\hline Learning by doing & $17(85 \%)$ & $20(100 \%)$ & $17(85 \%)$ & $20(100 \%)$ \\
\hline Involvement in strategic planning & 0 & 0 & $13(65 \%)$ & $13(65 \%)$ \\
\hline Teamwork & $15(75 \%)$ & $15(75 \%)$ & $15(75 \%)$ & $13(65 \%)$ \\
\hline
\end{tabular}

Table 3. Knowledge transfer

Nineteen (95\%) founders exposed their children early to the family firm's environment; only in one case was the son-in-law not exposed early to the family firm environment. In the case of successors, the sample matches. According to successors, early exposure to the family firm is crucial for their interest in the family business. Nine (45\%) founders mentored their children, while 8 successors were mentored by a non-family member; one of the founders ( $5 \%$ ) compared apprenticeship to mentoring. Seventeen (85\%) successors reported being mentored or coached by a parent or nonfamily member, and one successor mentioned an external professional. The case studies revealed that apprenticeship is not a common way of transferring knowledge in Slovenian family firms. Learning by doing is seen as a very important way of transferring knowledge to the successors: Founders believed that letting children observe them at work and simply throwing them in the water to swim is a very good way of getting experience.

The founders did not report on the involvement of successors in the decision making. However, $13(65 \%)$ successors indicated that they participated in decision-making processes after they became actively involved in a family firm. Founders did not report involvement of successors in strategic planning processes. However, again, 15 (75\%) successors believed that they were involved in strategic planning processes, but not before their active involvement in 
the family firm. Fifteen (75\%) founders reported that they involved their children in teamwork. In the case of successors, the sample matches. Sixteen (80\%) successors found teamwork to be an important form of knowledge transfer.

\section{Conclusions}

Based on the results of our interviews with 20 founders (owners/managers) and their successors in family SMEs in Slovenia, we believe that entrepreneurialism (entrepreneurial competences of successors) and knowledge transfer (especially tacit knowledge, from founders to successors) in different forms are very important and crucial for effective succession in family SMEs, thereby contributing to the long-term sustainability of the family firms.

In terms of factors contributing to the formation and building of entrepreneurial competences, we identified work experience outside a family firm, family context (e.g., familiness), and formal education (i.e., in entrepreneurship), thus following the research findings of [26].

In the interviews, we researched how to prepare a competent leader, which included dealing with the transfer of knowledge (tacit knowledge) from the founders to the successors. We followed different authors in defining ways to transfer knowledge across family generations: early exposure of children to a family business [7, 27], mentoring [7, 9], apprenticeship [9], learning-by-doing process [9], teamwork [26, 42], participation in decision making [38], and involvement in the strategic planning processes [47].

Most of our findings are not unique, but follow similar results of previously mentioned authors. For example, according to [28, 30], founders believe that children's early exposure to the business is of particular importance in order to absorb tacit knowledge. Our interviewees confirmed that $95 \%$ of them were involved in a family firm since childhood, learning about the business through daily conversations at home as well. All (100\%) founders and successors found that the successors' early exposure to the family business environment was highly important for the development of their interest for the family firm.

According to [28, 30], children should become co-owners when they join a business while their parents are still active in a business. This finding also correlates with results of our research. Indeed, $45 \%$ of the founders had already transferred the ownership of the family firm entirely or partly to their successors. According to the same authors, successors should be found among family members as a business is considered stronger with family members involved. In our 20 cases, all founders found successors in their sons and daughters, but in 2 cases $(10 \%)$ the founders had to delegate top managerial functions to a non-family member (due to the request of the bank) or to a son-in-law, as the founder did not want to expose his three daughters to the top managerial position. Gender is not an issue of succession in family firms according to [44], and in our 20 cases this was confirmed.

Yet certain findings differ. According to [44], less than $60 \%$ of founders in Slovenia plan succession. Our results show that $65 \%$ of founders already transferred management and/or ownership to their successors; it was entirely transferred in $15 \%$ of family SMEs. According to 
$[20,22,29]$, family firms lack succession experiences. Our study revealed that the succession process is active in $60 \%$ of family SMEs, as in these firms management is already in the hands of successors or they have already become actively involved in management functions. In addition, $65 \%$ of family firms have female successors, following potential successors' capabilities and not the rule that the oldest child takes over a business, thereby contradicting [44].

[31] suggested that successors lack mentoring and proper training and feel uncertain about their capabilities to manage the firm, while our research results show that $85 \%$ of successors have been mentored informally or formally by their parent or a non-family member and are active in the family business. All (100\%) successors and $95 \%$ of founders indicated that mentoring is very important to support the development of tacit knowledge by successors. Other forms of transferring knowledge (e.g., learning by doing) is very high on the priority ladder among founders and successors (100\% found it important, $85 \%$ practice it), as it is a perfect way of learning the tricks of the trade [9]. However, apprenticeship is not implemented as often as mentoring (50\%); teamwork and participation in decision making and strategic planning processes are more common once successors become actively involved in a family firm $(65 \%)$.

The authors argue that successors' entrepreneurial competences are of crucial importance for the smooth and effective realization of succession and for the innovativeness and viability of a family business in the next family generation. The research revealed factors contributing to the development of entrepreneurial competences: Formal education, work experience outside a family firm, and familiness are all very important and contribute significantly to the effective succession in family firms.

In our cases, all successors (100\%) believe that formal education-especially in the business field -is very important; they are very well educated $(80 \%$ hold a higher professional or university degree) and are trained at the academic level and thus exposed to new ideas and trends in management and business [26].

Experiences from both of the academic institutions, EBF and GEA-FE, offering undergraduate and postgraduate programs in entrepreneurship show students' growing interest in entrepreneurship at both levels. Part-time students especially expect know-how to upgrade their insights into the entrepreneurial world and to gain from pragmatic experience from different fields of activities and from different aspects that faculty shares with them. They also look for networking. Full-time students, many of them children from family business owners, appreciate theoretical background in their major business fields (e.g., marketing, finances, strategic planning, business planning) and want to combine theoretical platforms with project work.

External working experiences are very appreciated by the successors as they enable a more detached perspective over how to run and how to introduce changes and innovation in the business [9], but in our cases we ran into a problem of an economic situation that does not offer many opportunities and access to fresh knowledge in other firms. As a result, $60 \%$ of successors have no working experience in other firms, and most of the others have completed only short internships or obligatory training in other firms. All founders and successors (100\%) found 
familiness to be highly important for sustainability of a family firm and agreed that familiness is a competitive advantage of the family firm [8].

Building on our research, we can propose several areas for further study. In combination with our quantitative data collection, we propose the quantitative measurement of the constructs of familiness, entrepreneurial competences, and the transfer of knowledge and their relationship with innovativeness as well. Future research should address the impact of social capital and social networks as facilitators of know-how mobility and sharing between firms and individuals, contributing to the promotion of innovation in family firms. The question of the relationship between the stated constructs and a family firm's performance should be addressed in future studies as well.

Our research findings have implications for practice as they provide useful cognitions for stakeholders involved in the succession process (i.e., family members) as well as professionals dealing with family firms' succession issues and innovativeness. The evidences from the research indicate that importance of finding balance between the interests of a family on the one side and needs of a business on the other side. There is a danger of inefficient use of the entrepreneurial spirit, potential and family values, with available resources that should contribute to better business performance and/or satisfaction of a family. When doing forecasts for the future, family businesss' owners/managers may discover that no opportunities exist for the development of the mature business. In such a case they should reconsider the family attitude towards inclusion of the outside shareholders and/or even decide on selling a part of the family business.

Based on the findings, family businesses are found to be more customer-oriented. They might even consider using their family business specific feature as the marketing opportunity. Family businesses tend to spend more resources on their innovation activities suggesting that they are well aware of the importance of innovations for the development and long-term survival of a family business. Although the majority of participants reported that they had already started with the transition processes, one can claim that the transition of family businesses to the next generation has thus far not been a common practice in both Slovenia and other transition economies. This indicates a possible gap in knowledge as well as experiences regarding succession that might cause serious problem in the near future. Therefore, adequate measures are necessary on the national level in order to provide support to family businesses when preparing the transfer of ownership and leadership to the next generation.

This also suggests that knowledge about the family businesses succession should be improved at all levels. Education and training have important role in raising awareness of the succession issues and in creating and disseminating knowledge to the family businesses owners/managers. This is of special importance in Slovenia due to the fact that family business succession is quite a new issue.

From the point of view of both academic institutions studied, which already offer within their specialized programs courses on family entrepreneurship, it is advisable to renew the existing programs and provide more courses focused on innovativeness and innovation management, especially sources of innovation with concepts of commercially viable innovation, strategy of 
innovation, marketing of innovation, and the financing and controlling of innovation, thereby partly filling the knowledge gap. Knowledge on innovation management is crucial and contributes to the increased competitiveness of family firms and successful succession of potential successors of family businesses in dynamic, changing business environments.

\section{Author details}

Mojca Duh ${ }^{1 *}$, Marina Letonja ${ }^{2}$ and Jaka Vadnjal ${ }^{2}$

*Address all correspondence to: mojca.duh@uni-mb.si

1 Faculty of Economics and Business, University of Maribor, Maribor, Slovenia

2 GEA College of Entrepreneurship, Piran, Slovenia

\section{References}

[1] Barney JB. Firm resources and sustained competitive advantage. Journal of Management 1991;17(1) 99-120.

[2] Bird HB, Welsch H, Astrachan JH, Pistrui D. Family Business research: The evolution of an academic field. Family Business Review 2002;15(4) 337-350.

[3] Bjuggren PO, Sund LG. Strategic Decision Making in Intergenerational Successions of Small- and Medium-Sized Family-Owned Businesses. Family Business Review 2001;14(1) 11-23.

[4] Boyd J, Upton N, Wircenski M. Mentoring in Family Firms: A Reflective Analysis of Senior Executives' Perception. Family Business Review 1999;12(4) 299-309.

[5] BU University study program. Study field Entrepreneurship. http://www.epf.unimb.si/stud_prog/bu/Vsebina/podjetnistvo.aspx (accessed 8 July 2014).

[6] BM Master study program. Study field Entrepreneurship and Innovation. http:// www.epf.uni-mb.si/stud_prog/bm/Vsebina/podjetnistvo_in_inoviranje.aspx (accessed 9 July 2014).

[7] Cabrera-Suárez K, De Saa-Pérez P, García-Almeida D. The succession process from a resource and knowledge-based view of the family firm. Family Business Review 2001;14(1) 37-46.

[8] Campbell ND, Heriot KC, Welsh DHB. The black box: Unraveling family business succession. New England Journal of Entrepreneurship 2007;10(2) 9-14. 
[9] Chirico F. Knowledge accumulation in family firms: Evidence from four case studies. International Small Business Journal 2008;26(4) 433-462.

[10] Chirico F, Salvato C. Knowledge Integration and Dynamic Organizational Adaptation in Family Firms. Family Business Review 2008;21(2) 169-181.

[11] Chrisman JJ, Chua JH, Steier LP. An introduction to theories of family business. Journal of Business Venturing 2003;18(4) 441-448.

[12] De Massis A, Kotlar A. The case study method in family business research: Guidelines for qualitative scholarship. Journal of Family Business Strategy 2014;5(1) 15-29.

[13] Donckels R, Fröhlich E. Sind Familienbetriebe wirklich anders? Europäische STRATOS-Efrahrungen. Internationales Gewerbearchiv 1991;4 219-235.

[14] Donckels R, Lambrecht J. The Re-emergence of Family-Based Enterprises in East Central Europe: What Can Be Learned from Family Business Research in the Western World? Family Business Review 1999;12(2) 171-188.

[15] Duh M. Razvojne posebnosti družinskega podjetja (Developmental particularities of a family enterprise). PhD thesis. University of Maribor; 1999.

[16] Duh M. Family enterprises as an important factor of economic development: the case of Slovenia. Journal of Enterprising Culture 2003;11(2) 111-130.

[17] Duh M. Overview of family business relevant issues, Country fiche Slovenia. Research project. University of Maribor; 2008.

[18] Duh M. Distinctive characteristic of family business and supporting infrastructure: comparison of Slovenia with EU and other countries. In: Širec K. (ed.) Dynamics of Slovenian entrepreneurship: Slovenian entrepreneurship observatory 2008. Maribor: Faculty of Economics and Business; 2009. p105-121.

[19] Duh M. Family business succession as knowledge creation process. Kybernetes 2014;43(5) 699-714.

[20] Duh M, Tominc P. Pomen, značilnosti in prihodnost družinskih podjetij (Importance, characteristics and future of family enterprises). In: Rebernik M, Tominc P, Duh M, Krošlin T, Radonjič G. Slovenski podjetniški observatorij 2004, 2. del (Slovenian entrepreneurship observatory 2004, 2. part). Maribor: Faculty of Economics and of Maribor; 2005. p19-31.

[21] Duh M, Tominc P. Primerjalna analiza družinskih in nedružinskih podjetij v Sloveniji (Comparable analysis of family and non-family enterprises in Slovenia). In: Rebernik M, Tominc P, Duh M, Rus M, Pušnik K, Krošlin T, Bradač B, Močnik D. Slovenski podjetniški observatorij 2005 (Slovenian entrepreneurship observatory 2005). Maribor: Faculty of Economics and Business; 2006. p59-68.

[22] Duh M, Tominc P, Rebernik M. Succession issues within family enterprises in Slovenia. Društvena istraživanja 2007;16(4/5) 751-779. 
[23] Dumas C. Women's pathways to participation and leadership in family-owned firms. Family Business Review 1998;11 219-228.

[24] Dyck B, Mauws M, Starke FA, Mischke GA. Passing the baton. The importance of sequence, timing, technique and communication in executive succession. Journal of Business Venturing 2002;17(2) 143-162.

[25] Eisenhardt K. Building theories from the case study research. Academy of Management Review 1989;14(4) 532-550.

[26] Ganzaroli A, Fiscato G, Pilotti L. Does business succession enhance firm's innovation capacity? Results from an exploratory analysis in Italian SMEs. Working paper [n. 2006-29], 2nd Workshop on Family Firm Management Research. Nice, Italy; 2006. http://ideas.repec.org/p/mil/wpdepa/2006.29.html (accessed 5 February 2014).

[27] Gersick KE, Davis JA, McCollom Hampton M, Lansberg I. Generation to Generation. Life Cycles of the Family Business. Boston: Harvard Business School Press; 1997.

[28] Glas M. Družinska podjetja v Sloveniji: kaj vemo o njih? (Family businesses in Slovenia: what do we know about them?). In: Proceedings of the 5th International Conference Challenges and Opportunities of EU Enlargement for SMEs in CEI Countries, Piran, Slovenia; 2003. p143-162.

[29] Glas M, Vadnjal J. Transition of businesses into the next generation in Slovenia. International project on the transfer of family firms INTERREG IIIC. University of Ljubljana; 2005.

[30] Glas M, Vadnjal J, Čoh M. Family businesses in Slovenia-how do they differ from the EU? In: Proceedings of the International Conference An Enterprise Odyssey: Building Competitive Advantage [Compact disc ed.], Graduate School of Economics and Business, University of Zagreb, Zagreb; 2004.

[31] Glas M, Čoh M, Višnar A, Vadnjal J. Transgenerational views on the success and the future development of family firms. In: Sustaining the entrepreneurial spirit over time: implications for your companies, family business and established companies. 35th EISB Conference, Barcelona, 12-14 September; 2005. http://wapp.iese.edu/eisb/ papereisb.asp/ (accessed July 5, 2007).

[32] Glas M, Herle J, Lovšin Kozina F, Vadnjal, J. The state of family firm management in Slovenia. In proceedings of $2^{\text {nd }}$ Workshop on Family Firm Management Research, EIASM, Nice, Italy; 2006.

[33] Habbershon TG, Williams ML. A resource based framework for assesing the strategic advantage of family firms. Family Business Review 1999;12(1) 27-39.

[34] Habbershon TG, Williams ML, MacMillan IC. A United Systems Perspective of Family Firm Performance. Journal of Business Venturing 2003;18(4) 451-465. 
[35] Hall R. The strategic analysis of intangible resources. Strategic Management Journal 1992;13(2) 135-144.

[36] Handler WC. Succession in Family Business: A Review of the Research. Family Business Review 1994;7(2) 133-157.

[37] Jaskiewicz P, Uhlenbruck K. Is Nepotism Good or Bad? Types of Nepotism and Implications for Knowledge Management. Family Business Review 2013;26(2) 121-139.

[38] Kellermanns FW, Eddelston KA. Feuding Families: When Conflict Does a Family Firm Good. Entrepreneurship Theory and Practice 2004;28(3) 209-228.

[39] Kocijan S. Explore the world of FEB. Informational Book. Maribor: Faculty of Economics and Business; 2008.

[40] Lambrecht J, Lievens J. Pruning the Family Tree: An Unexplored Path to Family Business Continuity and Family Harmony. Family Business Review 2008;21(4) 295-313.

[41] Le Breton-Miller I, Miller D, Steier LP. Toward an integrative model of effective FOB succession. Entrepreneurship Theory and Practice 2004;28(3) 305-328.

[42] Litz RA, Kleysen RF. Your Old Men Shall Dream Dreams, Your Young Men Shall See Visions: Toward a Theory of Family Firm Innovation with Help from the Brubeck Family. Family Business Review 2001;14(4) 335-352.

[43] Longenecker JG, Schoen JE. Management Succession in the Family Business. In: Aronoff CE, Astrachan JH, Ward JL. (eds.) Family Business Sourcebook II. Marietta: Business Owner Resources; 1996. p87-92.

[44] Lovšin Kozina F. Kritične točke uspešnega medgeneracijskega prehoda v slovenskih družinskih podjetjih (Critical points of successful intergenerational transfer in Slovenian family businesses). PhD thesis. University of Ljubljana; 2006.

[45] Mandl I. Overview of Family Business Relevant Issues, Final Report, Austrian Institute for SME Research, Vienna; 2008. http://ec.europa.eu/enterprise/entrepreneurship/ craft/family_business/family_business_en.html (accessed 31 July 2009).

[46] Matz Carnes C, Ireland D. Familiness and Innovation: Resource Bundling as the Missing Link. Entrepreneurship Theory and Practice 2013;37(6) 1399-1419.

[47] Mazzola P, Marchision G, Astrachan J. Strategic planning in family business: A powerful developmental tool for the next generation. Family Business Review 2008;21(3) 239-258.

[48] Miller D, Steier L, Le Breton-Miller I. Lost in time: intergenerational succession, change, and failure in family business. Journal of Business Venturing 2003;18(4) 513-531.

[49] Močnik D. Temeljne značilnosti slovenskega podjetništva v primerjavi z evropskim (Basic characteristics of Slovenian entrepreneurship in comparison with the Europe- 
an). In: Širec K, Rebernik M. (eds.) Razvojni potenciali slovenskega podjetništva: Slovenski podjetniški observatorij 2011/12 (Developmental potentials of Slovenian entrepreneurship: Slovenian entrepreneurship observatory 2011/12). Maribor: Faculty of Economics and Business, Maribor; 2012. p15-28.

[50] Morris MH, Williams RO, Allen JA, Avila RA. Correlates of success in family business transitions. Journal of Business Venturing 1997;12(5) 385-401.

[51] Motwani J, Levenburg NM, Schwarz TV, Blankson C. Succession Planning in SMEs: An Empirical Analysis. International Small Business Journal 2006;24(5) 471-495.

[52] Nonaka I, Toyama R, Konno N. SECI, Ba and Leadership: A Unified Model of Dynamic Knowledge Creation. Long Range Planning 2000;33(1) 5-34.

[53] Nonaka I, von Krogh G. Tacit Knowledge and Knowledge Conversion: Controversy and Advancement in Organizational Knowledge Creation Theory. Organization Science 2009;20(3) 635-652.

[54] Reay T. Publishing Qualitative Research. Family Business Review 2014;27(2) 95-102.

[55] Royer S, Simons R, Boyd B, Rafferty A. Promoting Family: A Contingency Model of Family Business Succession. Family Business Review 2008;21(1) 15-30.

[56] Sardesmukh SR, Corbett AC. The Duality of Internal and External Development of Successors: Opportunity Recognition in Family Firms. Family Business Review 2011;24(2) 111-125.

[57] Sharma P. An Overview of the Field of Family Business Studies: Current Status and Directions for the Future. Family Business Review 2004;17(1) 1-36.

[58] Sharma P, Rao AS. Successor Attributes and Canadian Family Firms: A Comparative Study. Family Business Review 2000;13(4) 313-322.

[59] Sharma P, Chrisman JJ, Chua JH. Succession Planning as Planned Behavior: Some Empirical Results. Family Business Review 2003;16(1) 1-14.

[60] Sirmon DG, Hitt MA. Managing resources: Linking unique resources, management and wealth creation in family firms. Entrepreneurship Theory and Practice 2003;27(4) 339-358.

[61] Steier L. Next generation entrepreneurs and succession: An exploratory study of modes and means of managing social capital. Family Business Review 2001;14(3) 259-276.

[62] GEA College of Entrepreneurship. Study program first level-Entrepreneurship. http://www.gea-college.si/fakulteta-za-podjetnistvo/studijski-programi-1-stopnje/ visokosolski-studijski-program-podjetnistvo/predmetnik/ (accessed 18 July 2014). 
[63] GEA College of Entrepreneurship. Study program second level-Entrepreneurship. http://www.gea-college.si/fakulteta-za-podjetnistvo/studijski-programi-1-stopnje/ visokosolski-studijski-program-podjetnistvo/predmetnik/ (accessed 18 July 2014).

[64] Szulanski G. Exploring internal stickiness. Impediments to the transfer of best practice within the firm. Strategic Management Journal 1996;17(Special Winter Issue) 27-43.

[65] Vadnjal J. Razvojna naravnanost družinskih podjetij v Sloveniji (Delopmental orientation of family enterprises in Slovenia). PhD thesis. University of Ljubljana; 2005.

[66] Vadnjal J. Innovativeness and inter-generational entrepreneurship in family businesses. In: Cooperation between the economic, academic and governmental spheres - mechanisms and levers proceedings of the 26th Conference on Entrepreneurship and Innovation, Maribor; 2006.

[67] Ward JL. Keeping the Family Business Healthy. San Francisco: Jossey-Bass Inc. Publishers; 1987.

[68] Zahra SA. Entrepreneurial risk taking in family firms. Family Business Review 2005;18(1) 23-40.

[69] Yin KR. Case Study Research, Design and Methods. Third Edition, Thousand Oaks, CA: Sage Publications; 2003. 